\title{
EFISIENSI PENJUALAN TEMBAKAU VERGINIA BERDASARKAN BENTUK DAUN BASAH DAN DAUN KERING DI KECAMATAN SAKRA BARAT KABUPATEN LOMBOK TIMUR
}

\author{
Jamaluddin ${ }^{1)}$ \\ Mimi Cahayani ${ }^{2)}$ \\ Universitas Islam Al-Azhar1) \& 2) \\ Email: Ju56813@gmail.com
}

Email: Mimigazali09@gmail.com

\begin{abstract}
To be able to determine the type of tobacco that provides maximum profit for farmers in Lita from the types of tobacco leaf forms that are sold, it is necessary to conduct a study entitled "Economic Efficiency of Virginia Tobacco Farming Based on the Forms of Selling Wet Leaves and Dry Leaves in Sakra Barat District, East Lombok Regency" . Efficiency measurement using Revenue Cost Ratio $(R / C)$. The unit of analysis in this research is farmers who do Virginia tobacco farming in the form of selling wet and dry leaves. Of the 16 Villages in West Sakra Subdistrict, four villages were selected by purposive sampling with the consideration that the four villages had the highest number of Virginia tobacco farmers. The four villages are Rensing Village, Jero gunung Village, Pematung Village, Rensing Raya Village. Determination of respondents is done by Quota Sampling, namely sampling based on a certain amount / quota. Based on the results of the analysis, the average income of wet leaf farmers was IDR 7,670,120 / LL or IDR. 065,013 / Ha and the average income of dry leaf farmers was IDR 60,832,656 / LLG or IDR 40,555,104 / Ha. The average $R$ / C value for the sale of wet leaves is 2.4 and the $R / C$ value for dry leaves is 3.4, it means that the sale of wet leaves and dry leaves is equally feasible because they have a higher $R$ / $C$ value $>1$. compared to wet leaf sales.
\end{abstract}

Keywords: Sales Efficiency, Tobacco Sales, Virginia Tobacco

\section{Latar Belakang}

Nusa Tenggara Barat (NTB) merupakan Provinsi penghasil tembakau verginia yang cukup potensial di Indonesia. Perkembangan tembakau Virginia di NTB masih terkonsentrasi di pulau Lombok, sehingga lebih di kenal dengan istilah tembakau Virginia Lombok. Pada tahun 2015 luas areal pengembangan tembakau verginia kurang lebih $19.840 \mathrm{Ha}$.

Kabupaten Lombok Timur merupakan kabupaten dengan luas lahan dan produksi tembakau virgina terbesar di antara kabupaten lainnya khususnya di NTB. Kecamatan Sakra barat merupakan salah satu kacamata yang berada di kabupaten Lombok timur dengan luas areal tanam tembakau Virginia sebesar $1.554 \mathrm{Ha}$ dengan jumlah produksi sebesar 1.925 ton 1. Berdasarkan kondisi yang ada di lapangan petani tembakao Virginia dalam melakukan

\footnotetext{
${ }^{1}$ Badan Pusat Statistik Provinsi NTB, 2014. Kantor badan pusat statistik provinsi NTB.
} 
Jurnal Kompetitif : Media Informasi Ekonomi Pembangunan, Manajemen dan Akuntansi Vol. 6 No. 2, September 2020

usaha taninya terdapat dalam bentuk penjualan yakni petani yang melakukan penjulan dalam bentuk daun basah dan petani yang melakukan penjualan dalam bentuk kering.

Petani yang melakukan penjualan tembakau dalam bentuk daun basah adalah petani yang melakukan usaha tani mulai dari menanam sampai panen dan langsung menjual hasil tembakaunya kepada pengumpul dalam ukuran kwintal tanpa melalukan proses pasca panen di mana pengumpul akan mengelolah daun tembakao tersebut menjadi kering dan penjual kepada perusahaan, sedangkan petani yang melakukan penjualan daun tembakau dalam bentuk kering adalah petani yang melalukan kegiatan usaha mulai dari menanam hingga panen. Proses berikutnya merupakan pasca panen yang menyebabkan petani mengeluarkan tambahan biaya seperti upah tenaga kerja penggelantangan, pengovenan dan sortasi daun tembakau serta biaya bahan bakar untuk pengonvenan daun tembakau basah menjadi kering sebelum di jual kepada pengumpul dalam ukuran kwintal. Berdasarkan tahapan proses produksi usaha tani tembakau Virginia daun basah menjadi kering bisa meningkatakan pendapatan petani dan efisiansi ekonomi usaha tani tembakau Virginia di kecamatan Terara kabupaten Lombok timur.

Ditinjau dari teknologi yang di gunakan oleh petani dalam mengusahan tanaman tembakau Virginia tersebut dapat di katakana masih sangat sederhana terutama dalam hal penggunaan tenaga kerja seperti petani di kabupaten Lombok timur. Pada umumnya petani yang mengusahakan tembakau Virginia di kecamatan sakra barat masi mengandalkan tenaga manusia baik untuk persiapan lahan, penanaman, pemeliharaan, pemanen maupun penanam basah menjadai daun kering semuanya menggunakan traktor. Hal ini akan berpengaruh pada biaya serta pendapatan petani dalam mengusahakan usaha tembakau Virginia di kecamatan sakra barat kabupaten Lombok timur.

\section{Dasar Teori}

Usaha Tani adalah pengolahan sumber daya alam tenaga kerja, permodalan dan Skill lainnya untuk menghasilkan suatu produk pertanian secara efiktif dan efisien ${ }^{2}$. Keberhasilan suatau usaha Tani dapat di lihat dari kemampuan memberikan pendapat yang tinggi. Pendapatan yang di terima mampu mencukupi keseluruhan biayayang di keluarkan oleh usaha tani itu minimal berada dalam keadaan yang lebih baik dari semula.

Menurut Soekartawi ${ }^{3}$. Pendapatan usahatani adalah selisih antara penerimaan dan semua biaya. Analisis pendapatan mempunyai dua tujuan yaitu, untuk menggambarkan

\footnotetext{
${ }^{2}$ Kadarsan,2011.Pengantar Ekonomi Pertanian PT. Bima Aksara,Jakarta.

${ }^{3}$ Soekartawi, 1989.Pendapatan Usaha Tani.
} 
Jurnal Kompetitif : Media Informasi Ekonomi Pembangunan, Manajemen dan Akuntansi Vol. 6 No. 2, September 2020

keadaan sekarang suatu kedaan usahatani dan untuk menggambarkan keadaan yang akan datang dari suatu perencanaan atau tindakan.

Pendapatan yang diperoleh petani dari suatu kegiatan usahataninya diperhitungkan dari nilai produksi dikurangi biaya. Pendapatan ini akan mendorong petani untuk mengalokasikanya dalam berbagai kegunaan seperti biaya produksi priode selanjutnya, tabungan dan pengeluaran lain untuk memenuhi kebutuhan keluarganya, Soekartawi ${ }^{4}$

Efisiensi merupakan hasil perbandingan antara output fisik dan input fisik. Semakin tinggi rasio output terhadap input maka semakin tinggi tingkat efisiensi yang di capai. Efisiensi juga dapat di jelaskan sebagai pencapaian output maksimum dari pennguna sumber daya tertentu, jika output yang di hasilkan lebih besar dari pada sumber daya yang di gunakan maka semakin tinggi pula tingkat efisiensi yang akan dicapai.

Menurut Samsuber Saleh ${ }^{5}$ Termbakau Virginia berasal dari Amerika Serikat.Tembakau Virginia mempuyai daun yang berwarna kekuningan- kuningan. Bentuk daunnya genjang sampai jorong, tetapi kadang kadang bulat telur. Ujungnya daunya lancip sampai meruncing, setiap batang biasanya memiliki jumlah daun sekitar 20-30 helai yang tidak bertangkai dan tertancap pada batangnya dengan posisi tegak membentuk 45 .

Pengolahan adalah peroses yang berlangsung dari tembakau daun basah menjadi tembakau kering yang memenuhi syarat -syarat kualitas yang diinginkan atau dimintai oleh pasar untuk bahan pembuatan rokok . Cara pengolahan merupakan factor penentu untuk memperoleh hasil akhir. Mulai cara atau proses pengolahan tertentu melalui kultur tehnis tertentu , akan diperoleh hasil kerosok dengan mutu atau kualitas yang tertentu pula, Abdullah dan Soedarmanto ${ }^{6}$

Penelitian terdahulu dari Padhilah $(2010)^{7}$ tentang “ Analisis Pendapatan Petani Tembakau Virginia Pada Berbagai Status Penguasaan Lahan di Kabupaten Lombok Tengah"metode penelitian yang digunakan adalah metode deskriftif sedangkan pengumpulan data menggunakan metode snow ball sampling. Hasil penelitian ini menunjukkan bahwa, dari hasil penelitian dan pembahasan dapat ditarik kesimpulan bahwa tingkat pendapatan yang diterima petani tembakau Virginia berbeda secara nyata untuk petani status lahan sewa Rp. 27.846.827.48 dan untuk petani status lahan milik Rp.25.285.876.12 per Ha. Adapun

\footnotetext{
${ }^{4}$ Soekartawi, 1989.Pendapatan Usaha Tani.

${ }^{5}$ Samsubar Saleh, 2002.Pengantar Teori Ekonomi, PT.Raja GrafindoPersada.

${ }^{6}$ Abdullah dan Soedarmanto,2003.Budidaya Tembakau, CV. Yasaguna,Jakarta.

${ }^{7}$ Padhilah, 2006.Studi Pendapaan dan Efisiensi Ekonomi dan Usaha Tani Tembakau Rakyat dan Usaha Tani Cabai di Kecamatan Selong,Kabupaten Lombok Timur,Skripsi Universitas Mataram.
} 
Jurnal Kompetitif : Media Informasi Ekonomi Pembangunan, Manajemen dan Akuntansi Vol. 6 No. 2, September 2020

hasil dari factor-faktor yang berpengaruh terhadp pendapatan petani adalah luas lahan , modal dan pengalaman sedanagkan yang lain non signifikan terhadap pendapatan petani tembakau Virginia.

Mardiana (2012) ${ }^{8}$ Tentang “ Studi Perbandingan Pendapatan dan Efisiensi Ekonomi Ushatani Tembakau Rakyat dan Usahatani cabai di Kecamatan Selong kabupaten Lombok Timur " Metode penelitian ini menggunakan metode deskriftif dengan tehnik survey, penentuan kelurhan ditentukanoleh purposive sampling . penelitian ini menyimpulkan bahwa jumlah biaya yang dikeluarkan dalam usahatani rakyat dalah sebesar Rp.6.025.689.83/Ha sedangkan usaha tani cabai sebesar 4.305.971.31/Ha. Tingkat efisien yang diperoleh adlah sebesar 1,78 untuk usahatani tembakau rakyat dan 1,73 untukusahatani cabai, berdasarkan hasil Analisis yang diperoleh pendapatan yang diterima dalam usahatanitembakau rakyat adalah sebesar Rp. 10.735.872.67/Ha sedangkan hasil petani cabai adlah sebesar Rp.7.481.528,69/Ha.Berdasarkan hasil analisis yang diperolek bahwa usaha tani tembakau rakyat dan usahatani cabai Efisien secara ekonomi dan layak untuk diusahakan dengan $\mathrm{R} / \mathrm{C}$ sebesar1,78 untuk usahatani tembakau rakyat dan R/C sebesar 1,73 untuk usahatani cabai maslah yang dihadpi petani tembakau rakyat dan cabai adalah kurangnya modal dan itensitas penyuluhan

\section{METODE PENELITIAN}

Penelitian yang digunakan dalam penelitian adalah kuantitatif dengan pendekatan deskriptif. Pengumpulan data primer terhadap responden dilakukan dengan teknik wawancara dan menggunakan daftar pertanyaan (kuisioner) yang ditanyakan kepada responden Nazir ${ }^{9}$

Penelitian ini dilaksanakan di kecamatan Sakra Barat Kabupaten Lombok Timur menngunakan data tahun,2014-2018. Kecamatan Sakra kabupaten Lombok Timur terdapat 18 Desa, dan dari 18 Desa tersebut di pilih 4 Desa porposif dengan pertimbangan bahwa 4 Desa tersebut memiliki jumlah tembakau virginia terbanyak 4 desa yang terpilih adalah desa jero gunung, Desa pematung, Desa Rensing, Desa Rensing Raya,dan total populasi adalah 535 orang. Responden di tetapkan sebanyak 30 orang secara kuota sampling yaitu pengambilan sampel berdasarkan jasa (kuota). Penentuan jumlah responden masing- masing Desa dilakukan secara kuota sampling. Jenis data yang dgunakan yaitu data Primer yang diperoleh secara langsung dari sumber daya atau dari narasumber informasi yaitu petani yang

\footnotetext{
${ }^{8}$ Mardiana, 2012.Studi Perbandingan Pendapatan dan Efisiensi Ekonomi.

${ }^{9}$ Moh. Nazir, 2014 “Metode Penelitian Terapan”, Ghalia Indonesia. Bogor.
} 
Jurnal Kompetitif : Media Informasi Ekonomi Pembangunan, Manajemen dan Akuntansi Vol. 6 No. 2, September 2020

melakukan usahatani pengolahan daun tembakau basah dengan daun yang kering di Kecamatan Sakra Barat Kabupaten Lombok Timur.

\section{Analisis biaya dan pendapatan}

Untuk mengetahui jumlah penerimaan usahatani tembakau Virginia dalam bentuk penjualan daun basah dengan daun yang kering dapat di hitung dengan rumus, soekartawi ${ }^{10}$ :

$$
\mathrm{TR}=\mathrm{Px} \mathrm{Q}
$$

Pendapatan uasaha tani tambakau Virginia dalam bentuk penjual daun basah dengan daun yang kering diukur dengan rumus:

Pendapatan $=$ TR - TC

Untuk mengetahui efisiensi usahatani tembakau Virginia berdasarkan bentuk penjualan daun basah dengan daun yang kering dilakukan dngan analisis $\mathrm{F} / \mathrm{C}$ rasio yang dipormulasikan sebagai berikut ( soekartawi,2009),

$$
\mathrm{R} / \mathrm{C} \text { rasio }=\mathrm{TR} / \mathrm{TC}
$$

\section{HASIL DAN PEMBAHASAN}

\section{Gambaran Umum Usahatani Tembakau Virginia Di Kecamatan sakra Barat} Kabupaten Lombok Timur

Tahapan usaha tani tembakau di awali dari proses pembibitan. Pembibitan adalah kegiatan menyemaikan biji hingga menjadi bibit siap tanam. Pembibitan dilakaukan untuk mendapatkan bibit yang baik sehingga menurunkan resiko kematian pada saat tahap penanaman. Pengolahan tanah atau persiapan lahan tanam disesuaikan dengan memeperhatikan jadwal persemaian dan umur bibit pada saat akan dipindahkan,maka waktu yang tepat untuk mempersiapkan lahan adalah dua bulan sebelum masa tanam. Kegiatan penanaman pada tembakau virginia dilakukan pada saat bibit telah berumur sekitar 45-55 hari. Tembakau yang telah ditanam perlu perawatan yang intensif untuk mendapatkan mutu tembakau yang baik. Tembakau yang telah ditanam perlu perawatan yang intensif untuk mendapatkan mutu tembakau yang baik. Daun tembakau sebagai bahan baku rokok memiliki nilai ekonomis cukup tinggi bila ditunjang dengan mutu daun yang baik. Untuk mendapatkan mutu dankwalitas yang baik dibutuhkan penanganan yang baik pula pada saat pemanenan. Daun- daun tembakau yang telah dipanen masih mengalami proses pengolahan sebelum sampai pada konsumen akhir. Proses yang

\footnotetext{
${ }^{10}$ Soekartawi, 1989.Pendapatan Usaha Tani.
} 
Jurnal Kompetitif : Media Informasi Ekonomi Pembangunan, Manajemen dan Akuntansi Vol. 6 No. 2, September 2020

berlangsung sejakdari daun proses yang berlangsung sejak dari daun basah menjadi kering hingga menjadi bahan akhir merupakan kegiatan pascapanen.

Biaya produksi adalah penjumlahan dari biaya-biaya yang dikeluarkan selama proses produksi dalam usahatani tembakau virginia yang berlangsung dalam satu kali musim tanam. Biaya ini meliputi : biaya variabel dan biaya tetap. Biaya variabel adalah biaya yang dikeluarkan tergantung pada besar kecilnya produksi yang terdiri dari biaya sarana produksi dan biaya tenaga kerja sedangkan untuk biaya tetap adalah biaya yang besar kecilnya tidak tergantung pada besar kecilnya produksi yang meliputi biaya sewa lahan, pajak tanah dan biaya penyusutan. Biaya produksi pada usahatani tembakau virginia berdasarkan bentuk penjualan daun basah dengan daun kering yang dimaksud dalam penelitian adalah semua pengeluaran yang digunakan untuk membiayai sarana produksi, tenaga kerja, penyusutan peralatan, dan lain-lain. Dalam kegiatan usahatani tembakau virginia biaya input produksi meliputi biaya variabel dan biaya tetap . Biaya variabel yang dihitung dalam penelitian ini meliputi biaya sarana produksi(pupuk, pestisida dan bahan bakar untuk menghasilkan tembakau kering) danbiaya tenaga kerja (luar Keluarga dan dalam keluarga), sedangkan biaya tetap yang dihitung dalam penelitian ini meliputi biaya penyusutan alat, dan pajak lahan.

Tabel 1.1. Rata-Rata Biaya Produksi, Pada Usahatani Tembakau Virginia berdasarkan bentuk Penjualan daun basah dengan daun yang Kering di Kecamatan Sakra Barat Kabupaten Lombok Timur

\begin{tabular}{|c|c|c|c|c|c|c|c|c|c|}
\hline \multirow[t]{3}{*}{ No } & \multirow{3}{*}{$\begin{array}{c}\text { Jenis } \\
\text { sarana } \\
\text { Produksi }\end{array}$} & \multicolumn{4}{|c|}{$\begin{array}{l}\text { Biaya Saprodi Usahatani Daun } \\
\text { Basah }\end{array}$} & \multicolumn{4}{|c|}{ Biaya Saprodi Usahatani Kering } \\
\hline & & \multicolumn{2}{|r|}{ Per LLG } & \multicolumn{2}{|r|}{ Per Haktar } & \multicolumn{2}{|r|}{ Per LLG } & \multicolumn{2}{|r|}{ Per Haktar } \\
\hline & & Jumlah & Nilai (Rp) & Jumlah & Nilai $(\mathrm{Rp})$ & Jumlah & Nilai $(\mathrm{Rp})$ & Jumlah & Nilai (Rp) \\
\hline \multicolumn{10}{|c|}{\begin{tabular}{l|l} 
Pupuk \\
\end{tabular}} \\
\hline & Urea $(\mathrm{Kg})$ & 100 & 200.000 & 183 & 366.748 & 30 & 460.000 & 53 & 306.667 \\
\hline & $\mathrm{ZA}(\mathrm{Kg})$ & 100 & 160.000 & 183 & 293.399 & 90 & 304.000 & 27 & 202.667 \\
\hline & KNO 3 & 100 & 2.000 .000 & 183 & 3.667 .482 & 147 & 2.933 .333 & 8 & 1.955 .556 \\
\hline & $(\mathrm{Kg})$ & 50 & 120.000 & 92 & 220.049 & 47 & 3 & 8 & 234.667 \\
\hline \multirow{2}{*}{\multicolumn{10}{|c|}{$\begin{array}{c}\text { NP } 36 \\
(\mathrm{Kg})\end{array}$}} \\
\hline & & & & & & & & & \\
\hline & Jumlah & \multicolumn{2}{|c|}{2.480 .000} & \multicolumn{2}{|c|}{3.547 .677} & \multicolumn{2}{|r|}{4.362 .667} & \multicolumn{2}{|r|}{ 3.859.556 } \\
\hline & Pestisida & & & & & & & & \\
\hline & Dolomit & 3 & 94.000 & 6 & 172.372 & & 208.000 & & 138.667 \\
\hline
\end{tabular}


Jurnal Kompetitif : Media Informasi Ekonomi Pembangunan, Manajemen dan Akuntansi Vol. 6 No. 2, September 2020

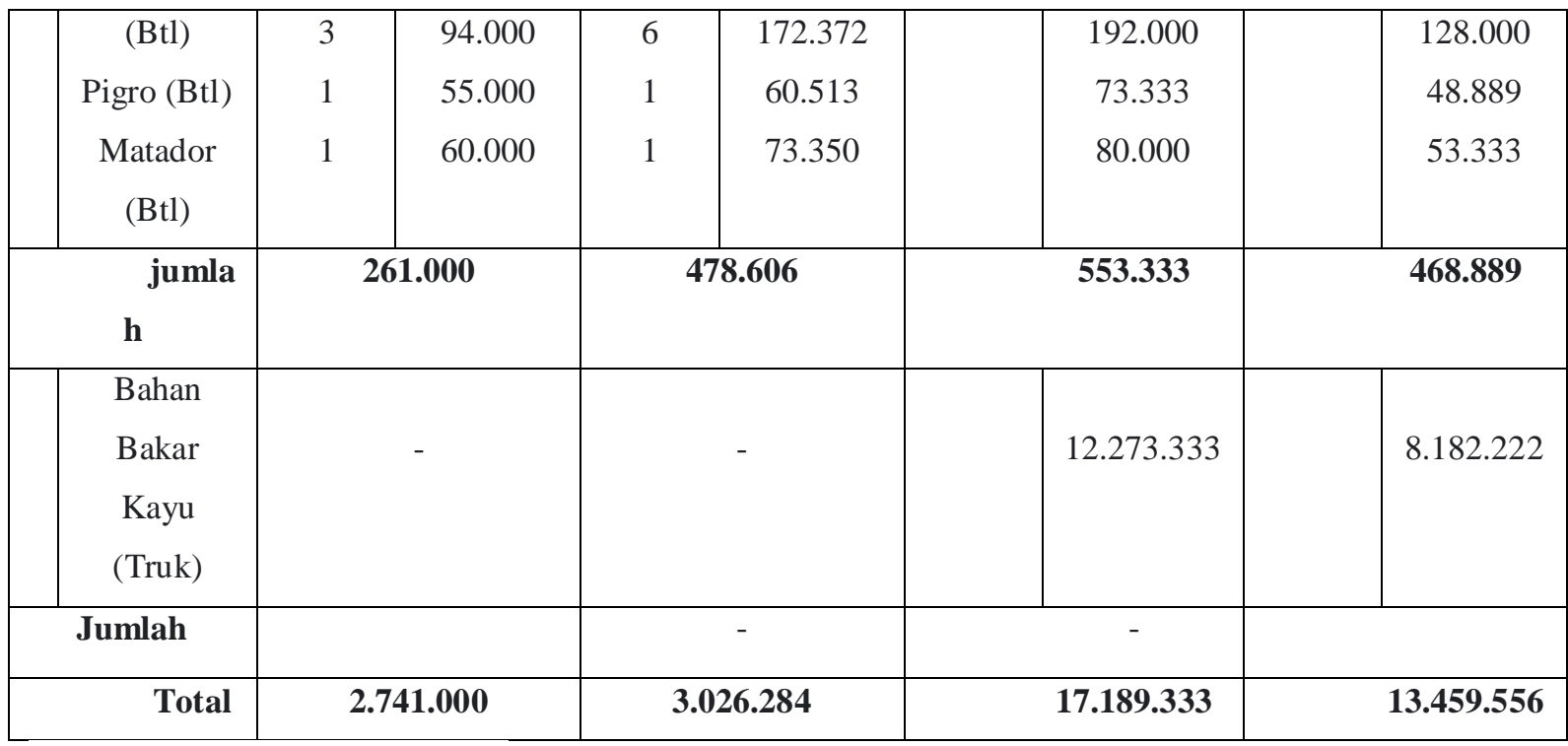

Sumber Data Primer di olah

Tabel di atas menunjukkan bahwa biaya Produksi pada usaha tani tembakau virginia berdasarkan bentuk penjualan kering membutuhkan biaya yang lebih besar dibandingkan pada usahatani tembakau virginia berdasarkan bentuk penjualan daun basah, hal ini disebabkan karna usahatani tembakau virginia dalam bentuk penjualan kering membutuhkan proses produksi yang lebih lama dan membutuhkan tenaga kerja yang lebih banyak dibandingkan dengan jenis usahatani tembakau virginia dalam bentuk penjualan daun basah.

Tenaga kerja adalah salah satu unsur penentu dan merupakan factor produksi yang mempunyai peranan penting dalam proses produksi. Adapun biaya tenaga kerja pada usahatani tembakau virginia berdasarkan bentuk penjualan daun basah dan kering dirinci selengkapnya pada tabel 1.2

Tabel 1.2. Rata-Rata Penggunaan dan Biaya Tenaga Kerja Pada Usaha tani Tembakau Virginia Berdasarkan Bentuk Penjualan Daun Basah dan Kering di Kecamatan sakra barat Kabupaten Lombok Timur

\begin{tabular}{|c|c|c|c|c|c|c|c|c|c|}
\hline \multirow[b]{3}{*}{ No } & \multirow[b]{3}{*}{ Jenis Kegiatan } & \multicolumn{4}{|c|}{ Usahatani Daun Basah } & \multicolumn{4}{|c|}{ Usahatani Kering } \\
\hline & & & otal Upah & enaga $\mathrm{r}$ & & & Total Upal & enaga & erja \\
\hline & & $\begin{array}{l}\text { Total } \\
\text { HKO }\end{array}$ & Per LLG & $\begin{array}{l}\text { Total } \\
\text { HKO }\end{array}$ & $\begin{array}{c}\text { Per } \\
\text { Haktar }\end{array}$ & $\begin{array}{l}\text { Total } \\
\text { HKO }\end{array}$ & Per LLG & $\begin{array}{l}\text { Total } \\
\text { HKO }\end{array}$ & Per Haktar \\
\hline
\end{tabular}


Jurnal Kompetitif : Media Informasi Ekonomi Pembangunan, Manajemen dan Akuntansi Vol. 6 No. 2, September 2020

\begin{tabular}{|l|l|l|l|l|l|l|l|l|l|}
\hline 1 & Pembajakan & 7,5 & 180.952 & 10,3 & 331.820 & 8,0 & 282.571 & 5,3 & 188.381 \\
2 & Mencangkul & 3,0 & 115.476 & 5,5 & 211.753 & 4,5 & 156.333 & 3,0 & 104.222 \\
3 & Sebar Benih & 9,8 & 439.333 & 18.0 & 805.623 & 18.8 & 750.476 & 12,5 & 500.3171 \\
4 & Penanaman & 4,7 & 125.714 & 5.8 & 230.527 & 6.2 & 179.810 & 4,3 & 119.873 \\
5 & Pemupukan & 23,4 & 342.857 & 43,0 & 628.711 & 39,6 & 1.511 .905 & 26,4 & 1.007 .937 \\
6 & Panen & - & 0 & - & 0 & 30,9 & 524.286 & 20.6 & 349.524 \\
7 & Glantang Daun & - & 0 & - & 0 & 30,9 & 3.302 .857 & 20,6 & 2.201 .905 \\
8 & Masuk Keluar & - & 0 & - & 0 & 22,3 & 402.857 & 14.9 & 268.571 \\
& Oven & & & & & & & & \\
& Sortasi & & & & & & & & \\
& & & & & & & & & \\
\hline & Total & $\mathbf{4 8 , 4}$ & $\mathbf{2 . 7 5 0 . 8 5}$ & $\mathbf{8 2 , 6}$ & $\mathbf{5 . 0 4 4 . 3 5}$ & $\mathbf{1 6 1 , 2}$ & $\mathbf{7 . 1 1 1 . 0 9 5}$ & $\mathbf{1 0 7 , 6}$ & $\mathbf{4 . 7 4 0 . 7 3 0}$ \\
& & $\mathbf{7}$ & & $\mathbf{9}$ & & & & & \\
\hline
\end{tabular}

Sumber : Data Primer diolah

Tabel tersebut menunjukkan bahwa biaya upah tenaga kerja yang di keluarkan petani dalam usahatani tembakau virginia dalam bentuk daun kering lebih besar dibandingkan dengan jenis usahatani tembakau virginia dalam bentuk penjualan daun basah, hal ini disebabkan karna penggunaan tenaga kerja dalam usahatani tembkau Virginia dalam bentuk daun kering lebih banyak dibandingkan dengan jenis usahatani tembakau virginia dalam bentuk daun basah terutama pada proses pasca panen (glantang daun, masuk keluar oven dan sortasi).

Penggunaan alat tertentu untuk kegiatan produksi pasti akan mengalami penyusutan yaitu hilangnya nilai ekonomis selama penggunaannya. Rincian rata-rata biaya penyusutan alat pada usahatani tembakau Virginia dalam bentuk penjualan daun basah dan kering di rinci selengkapnya pada tabel 1.3.

Tabel 1.3. Rata-rata Biaya Penyusutan Alat Petani Responden di Kecamatan sakra barat Kabupaten Lombok Timur

\begin{tabular}{|c|c|c|c|c|c|}
\hline \multirow[t]{4}{*}{ No } & \multicolumn{5}{|c|}{ Biaya Penyusutan } \\
\hline & \multirow[t]{3}{*}{ Jenis Alat } & \multirow{2}{*}{\multicolumn{2}{|c|}{$\frac{\text { Usahatani Tembakau Daun Basah }}{\text { Biaya }(\mathrm{Rp} / \mathrm{Musim})}$}} & \multirow{2}{*}{\multicolumn{2}{|c|}{$\begin{array}{c}\text { Usahatani Tembakau Kering } \\
\text { Biaya (Rp/ Musim) }\end{array}$}} \\
\hline & & & & & \\
\hline & & $\begin{array}{l}\text { Per LLG } \\
(\mathrm{Rp})\end{array}$ & $\begin{array}{l}\text { Per Haktar } \\
(\mathrm{Rp})\end{array}$ & $\begin{array}{l}\text { Per LLG } \\
\text { (Rp) }\end{array}$ & $\begin{array}{l}\text { Per Haktar } \\
\quad(\mathrm{Rp})\end{array}$ \\
\hline 1 & Sabit & 23.333 & 42.787 & 23.333 & 35.556 \\
\hline 2 & Cangkul & 130.040 & 238.460 & 216.733 & 244.489 \\
\hline 3 & Parang & 121.583 & 222.952 & 162.111 & 108.074 \\
\hline 4 & Gilantang & & & 236.667 & 157.778 \\
\hline 5 & Oven & & & 416.667 & 277.778 \\
\hline & Total & 109.630 & 201.033 & 1.055 .511 & 737.007 \\
\hline
\end{tabular}


Jurnal Kompetitif : Media Informasi Ekonomi Pembangunan, Manajemen dan Akuntansi Vol. 6 No. 2, September 2020

Sumber: Data Primer diolah

Tabel di atas menunjukkan bahwa biaya penyusutan pada usahatani tembakau Virginiadalam bentuk penjualan kering lebih besar di bandingkan pada usahatani tembakau virginia dalam bentuk penjualan daun basah karna, penggunaan alat pada usahatani tembakau virginia dalam bentuk penjualan kering lebih banyak terutama pada pembelian gelantang dan pembuatan oven.

Produksi, Biaya Produksi, Pendapatan dan Efisiensi Ekonomi Usahatani Tembakau Virginia Berdasarkan Bentuk Penjualan Daun Basah dan Kering

Produksi Dalam Penelitian ini adalah jumlah fisik tembakau virginia dalam bentuk daun basah dengan daun kering dalam satuan $(\mathrm{Kg})$. Nilai Produksi adalah jumlah produksi tembakau virginia dalam bentuk daun basah dan kering dikalikan dengan harga persatuan $(\mathrm{Kg})$ yang dinyatakan dalam kilogram (Rp). Sedangkan pendapatan diperoleh dari selisih nilai produksi dengan biaya produksi pada usahatani tembakau virginia dalam bentuk daun basah dengan daun kering.

Tabel 1.4. Rata-Rata Biaya Produksi, Nilai Produksi dan Pendapatan Petani Pada Usahatani Tembkau Virginia Berdasarkan Bentuk Penjualan Daun Basah dengan daun yang Kering

\begin{tabular}{|c|c|c|c|c|c|}
\hline \multirow[b]{2}{*}{ No } & \multirow[b]{2}{*}{ Uraian } & \multicolumn{2}{|c|}{ Usaha tembakau daun basah } & \multicolumn{2}{|c|}{ Usaha tani tembakau kering } \\
\hline & & Nilai/LLG(Rp) & $\begin{array}{c}\text { Nilai per hektar } \\
\text { (Rp) }\end{array}$ & Per LLG (Rp) & Per Hektar (Rp) \\
\hline $\begin{array}{l}1 . \\
2 . \\
3 . \\
4 \\
5 . \\
6 . \\
.\end{array}$ & $\begin{array}{l}\text { Biaya Produksi } \\
\text { Biaya Variabel } \\
\text { Pupuk (Kg) } \\
\text { Pestisida (Btl) } \\
\text { TKDK dan TKLK } \\
\text { (HKO) } \\
\text { Bahan Bakar Kayu } \\
\text { (Truk) } \\
\text { Biaya Tetap } \\
\text { Pajak } \\
\text { Penyusutan(RP) }\end{array}$ & $\begin{array}{c}2.480 .000 \\
261.000 \\
2.750 .857 \\
0 \\
17.978 \\
91.652\end{array}$ & $\begin{array}{c}3.547 .677 \\
478.606 \\
5.044 .359 \\
0 \\
32.967 \\
168.066\end{array}$ & $\begin{array}{c}4.362 .667 \\
553.333 \\
7.111 .095 \\
12.273 .333 \\
50.000 \\
1.055 .511\end{array}$ & $\begin{array}{c}3.859 .556 \\
468.889 \\
4.740 .730 \\
8.182 .222 \\
33.333 \\
670.341\end{array}$ \\
\hline & UMLAH TOTAL & 5.599 .380 & 10.267 .811 & 25.406 .011 & 16.937 .340 \\
\hline $\begin{array}{l}1 . \\
2 . \\
3 . \\
4 . \\
5 .\end{array}$ & $\begin{array}{l}\text { Harga Jual }(\mathrm{Rp}) / \mathrm{Kg} \\
\text { Jumlah Produksi }(\mathrm{Kg}) \\
\text { Nilai Produksi }(\mathrm{Rp}) \\
\text { Pendapatan }(\mathrm{Rp}) \\
\text { R/C Rasio }\end{array}$ & $\begin{array}{c}2.522 \\
5.278 \\
13.269 .500 \\
7.670 .120 \\
2,4\end{array}$ & $\begin{array}{c}2.522 \\
9.679 \\
24.332 .824 \\
14.065 .013 \\
2,4\end{array}$ & $\begin{array}{c}32.567 \\
2.603 \\
86.238 .667 \\
60.832 .656 \\
3,4\end{array}$ & $\begin{array}{c}32.567 \\
1.735 \\
56.514 .022 \\
40.555 .104 \\
3,4\end{array}$ \\
\hline
\end{tabular}

Sumber: Data Primer Diolah 
Jurnal Kompetitif : Media Informasi Ekonomi Pembangunan, Manajemen dan Akuntansi Vol. 6 No. 2, September 2020

Dari tabel 1.4. Menujukkan bahwa rata-rata biaya produksi untuk usahatani tembakau virginia daun basah sebesar Rp.5.559.380/LLG atau Rp.10.267.811/Ha dengan jumlah produksi sebesar 5.278 Kg/LLG atau 9.679 Kg/Hadengan kisaran harga jual Rp.2.000 s/d Rp.3.000 dengan rata-rata harga jualsebesar Rp.2.522 dengan nilai produksi sebesar Rp. 13.269.500/LLG atau SebesarRp.24.332.824/Ha dengan dengan kisaran pendapatan petani sebesar Rp. 6.356.944s/d 9.017.016 dengan rata-rata pendapatan petani sebesar Rp.7.670.120/LLG atausebesar Rp. 14.065.013/Ha dengan nilai R/C sebesar 2,4. Sedangkan untuk usaha tani tembakau virginia dalam bentuk daun kering rata-rata biaya produksi yang dikeluarkan petani sebesar Rp. 25.406.011/LLG atau Rp.16.937.340/Ha dengan kisaran harga jual Rp. 31.667 s/d Rp.33.667 dengan rata-rata harga jual sebesar Rp.32.567 dengan nilai produksi sebesar Rp. 86.238.667/LLG atau sebesar Rp.56.514.022/Ha dengan kisaran pendapatan petani sebesar Rp. 37.316.429 s/d Rp. 87.567.619 dengan rata-rata pendapatan petanisebesar Rp. 60.832.656/LLG atau sebesar Rp. 40.555.104/Ha dengan nilai R/Csebesar 3,4. Dari tabel 4.8. dapat di simpulkan bahwan kedua jenis usahatani tembakau Virginia baik dalam bentuk penjualan daun basah maupun dalam bentuk penjualan daun yang kering memiliki nilai $\mathrm{R} / \mathrm{C}>1$ ini menunjukkan bahwa kedua jenis usahatanai tersebut sama-sama efisien atau memiliki kelayakan untuk diusahakan, namun yang memiliki nilai R/C lebih tinggi dari kedua jenis usahatani tembakau virginia tersebut adalah jenis usahatani tembakau virginia dalam bentuk penjualan daun yang kering, karna jenis usahatani tembakau Virginia dalam bentuk penjualan daun kering memiliki nilai R/C sebesar 3,4 dibandingkan dengan jenis usahatani tembakau virginia dalam bentuk penjualan daun basah memiliki nilai R/C sebesar 2,4. Maka lebih tinggi pendapatan daun yang kering.

\section{Hambatan-Hambatan Pada Usahatani Tembakau Virginia}

Hambatan yang dihadapi petani pada usahatani tembakau virginia berdasarkan bentuk penjualan daun basah dengan daun yang kering di Kecamatan sacra barat Kabupaten Lombok Timur dapat dibagi menjadi dua, yaitu hambatan ekonomi dan non ekonomi. Hambatan ekonomi (HE) merupakan hambatan yang berasal dari keadaan yang berkaitan dengan aspek ekonomi petani responden dalam melakukan usahatani Tembakau virginia berdasarkan bentuk penjualan daun basah dan kering, yaitu terdiri dari permodalan, harga saprodi, dan system pemasaran, sedangkan hambatan non ekonomi 
Jurnal Kompetitif : Media Informasi Ekonomi Pembangunan, Manajemen dan Akuntansi Vol. 6 No. 2, September 2020

dapat berupa hambatan teknis (HT) dalam usahatani tembakau virginia dalam bentuk daun basah dan kering yangterdiri dari kondisi cuaca, kondisi lahan dan serangan hama serta penyakit.

Tabel 1.5.Hambatan-Hambatan Pada Usahatani Tembakau Virginia Berdasarkan bentuk Penjualan Daun Basah dan Kering di Kecamatan sakra baratKabupaten Lombok Timur Tahun 2018.Petani Responden

\begin{tabular}{|c|l|c|c|c|}
\hline No. & Hambatan - Hambatan & \multicolumn{2}{|c|}{ Petani Responden } & \multirow{2}{*}{ Ket. } \\
\cline { 3 - 4 } & & Jumlah & $\%$ & \\
\hline 1. & Permodalan & 2 & 6,6 & HE \\
2. & Harga Saprodi & 1 & 3,3 & HE \\
3. & Sistem Pemasaran & 1 & 3,3 & HE \\
4. & Kondisi Cuaca & 16 & 53,3 & HT \\
5. & Pengovenan & 10 & 33,3 & HT \\
\hline \multicolumn{2}{|l|}{ Jumlah } & 30 & 100.0 & \\
\hline
\end{tabular}

Sumber : Data Primer Diolah

Berdasarkan tabel 1.5. dapat dilihat bahwa dari 30 Petani Responden usahatan tembakau virginia yang mempengaruhi kegiatan usahatani tembakau virginia dalam bentuk daun basah dan kering adalah

1. Permodalan, jika dilihatdari segi pemodalan dari 30 terdapat 2 responden atau $6,6 \%$ yang mengalami kesulitan dari segi modal usahatani, karna sebagian besar petani respondenmenyisihkan uang hasil usahataninya kepada bank berupa tabungan bank, adapulapetani yang menginvestasikan uangnya berupa pembelian emas sebagai antisipasi petani ketika mengalami kekurangan modal dalam usahatani tembakau virginia,maka petani menggunakan jasa pegadaian untuk menggadai emas mereka untuk menambah modal untuk usahatani.

2. Harga saprodi, dilihat dari dari tabel 4.9hanya 3,3\% yang mengakami sesulitan terhadap harga saprodi, karna sebagianbesar petani dalam melakukan usahatani tembakau virginia dalam bentukpenjualan daun basah maupun dalam bentuk penjualan kering melakukanpembelian saprodi 1 s/d 2 bulan sebelum penanaman, guna mendapatkan harga yang lebih murah.

3. Sistem pemasaran, dalam usahatani tembakau Virginia dalam bentuk daun basah maupun dalam bentuk penjualan kering petani hanyasampai melakukan penjulan ke pengepul dengan harga yang sudah disepakatibersama, dengan cara semakin bagus 
Jurnal Kompetitif : Media Informasi Ekonomi Pembangunan, Manajemen dan Akuntansi Vol. 6 No. 2, September 2020

kualitas tembakau virginia yang dihasilkanpetani maka semakin tinggi pula harga yang di peroleh petani dan semakin besarpula pendapatan yang diperoleh petani.

4. Kondisi cuaca, kondisi cuaca memilikipengaruh yang paling besar dalam melakukan usahatani tembakau virginia dalambentuk penjualan daun basah dan dalam usahatani tembaku dalam bentuk penjualan kering dengan jumlah persentase sebesar 53,3\% Sebagian besar petaniresponden mengakui kondisi cuaca yang tidak menentu bisa berpengaruh terhadap menurunnya hasil produksi dan kuliatas dari daun tembakau yang dihasilkan.Perubahan cuaca secara ekstrim (hujan terus-menerus) terutama pada saat tembakau virginia menjelang panen menyebabkan menurunnya kualitas dari dauntembakau virginia dan mengurangi kuantitas hasil panen dan pendapatan petani Selain itu, permasalahan cuaca juga mempengaruhi kondisi fisik tanaman tembakau daun tembakau akan terlihat berwarna kecoklatan saat dijadikan keringakibat terguyur hujan secara berkala sehingga hasil dan produktivitasnya punmenurun.

5. Pengovean, teknik pengovenan juga meliki pengaruh dalam usahatani tembakau virginia dalam bentuk penjualan kering dengan jumlah persentase sebesar 33,3\% sebagian besar petani mengeluhkan tehnik pengovenan menggunakan bahan bakar kayu yang tidak semudah ketika petani masih dibolehkan menggunakan bahan bakar minyak tanah untuk melakukan proses pengovenan. Pengovenan menggunakan kayu membutuhkan pengawasan atau penjagaan yang lebih banyak terutama terhadap penetapan suhu panas yang dihasilkan kayu selama pengovenan untuk menghasilkan kering, karna petani masihmenggunakan cara yang tradisional dalam melakukan peroses pengovenan.

\section{KESIMPULAN}

Berdasarkan hasil analisis dan pembahasan, maka dapat ditarik beberapa kesimpulan sebagai berikut:

1. Rata-rata biaya produksi untuk usahatani tembakau virginia daun basah sebesar Rp.5.559.380/LLG atau Rp. 10.267.811/Ha dengan jumlah produksi sebesar 5.278 Kg/LLG atau 9.679 Kg/Ha dengan nilai produksi sebesarRp.13.269.500/LLG atau sebesar Rp.24.332.824/Ha sehingga rata-rata pendapatan petani sebesar Rp.7.670.120/LLG atau Rp.14.065.013/Ha. Sedangkan untuk usahatani tembakau virginia dalam bentuk kering rata-rata biaya produksi yang dikeluarkan petani sebesar 
Jurnal Kompetitif : Media Informasi Ekonomi Pembangunan, Manajemen dan Akuntansi Vol. 6 No. 2, September 2020

Rp.25.406.011/LLG atau Rp.16.937.340/Ha dengan jumlah produksi sebesar 2.603/LLG atau 1.735/Ha dengan nilai produksi sebesar Rp. 86.238.667/LLG atau Rp. 56.514.022/Ha sehingga rata-rata pendapatan petani sebesar Rp.60.832.656/LLG atauRp.40.555.104/Ha

2. Rata-rata Nilai R/C untuk usahatani tembakau virginia dalam bentuk penjualan daun basah sebesar 2,4 dan nilai R/C untuk usahatani tembakau virginia dalam bentuk daun kering sebesar 3,4. artinya usahatani tembakau Virginia baik dalam bentuk penjualan daun basah maupun dalam bentuk penjualan daun kering sama-sama efisien atau sama-sama layak untuk diusahakan karenamemiliki nilai R/C >1 namun usahatani tembakau virginia berdasarkan bentuk penjualan daun kering memiliki nilai $\mathrm{R} / \mathrm{C}$ lebih tinggi dibandingkan jenis usahatani tembakau virginia dalam bentuk penjualan daun basah.

3. Hambatan-hambatan yang mempengaruhi kinerja usahatani tembakau adalah permodalan, harga saprodi, sistem pemasaran, kondisi cuaca dan proses pengovenan.

\section{SARAN}

Berdasarkan hasil analisis, dapat disampaikan saran sebagai bahan pertimbangan untuk pengembangan usahatani tembakau virginia berdasarkan bentuk penjualan daun basah dengan daun kering, yaitu:

1. Perlu adanya uapaya dari pemerintah atau dinas terkait terhadap penerapan teknologi baru terutama teknologi yang memudahkan petani dalam melakukan proses pengovenan agar bisa mengurangi pengawasan atau penjagaan yang dilakukan petani selama dalam proses pengovenan.

2. Perlu adanya pengembangan pengetahuan terhad ap petani terutama pengetahuan terhadap perkiraan cuaca agar petani sebelum memulai usahatani tembakau virginia, bisa mengantisipasi atau meminimalisir semua kendala yang disebabkan oleh cuaca.

3. Perlu adanya motivasi khususnya untuk petani yang mengusahakan usahatani tembakau dalam bentuk penjualan daun basah untuk beralih ke usahatani tembakau virginia dalam bentuk penjualan daun kering, agar bisa meningkatkan pendapatan

\section{DAFTAR PUSTAKA}


Jurnal Kompetitif : Media Informasi Ekonomi Pembangunan, Manajemen dan Akuntansi Vol. 6 No. 2, September 2020

Abdullah dan Soedarmanto, 2003. Budidaya Tembakau, CV. Yasaguna,Jakarta.

Badan Pusat Statistik Provinsi NTB, 2014. Kantor badan pusat statistik provinsi NTB.

Kadarsan, 2011. Pengantar Ekonomi Pertanian PT. Bima Aksara,Jakarta.

Mardiana, 2012. Studi Perbandingan Pendapatan dan Efisiensi Ekonomi.

Moh. Nazir, 2014 “Metode Penelitian Terapan”, Ghalia Indonesia. Bogor.

Padhilah, 2006.Studi Pendapaan dan Efisiensi Ekonomi dan Usaha Tani Tembakau Rakyat dan Usaha Tani Cabai di Kecamatan Selong,Kabupaten Lombok Timur, Skripsi Universitas Mataram.

Samsubar Saleh, 2002. Pengantar Teori Ekonomi, PT.Raja Grafindo Persada.

Soekartawi, 1989. Pendapatan Usaha Tani. 